\title{
Moringa oleifera Seeds Extract Activity on \\ Enteropathogenic Escherichia coli and Aeromonas hydrophyla Cells in Aquatic Microcosm
}

\author{
Claire Stephane Metsopkeng \\ Laboratory of Hydrobiology and Environment, University of Yaounde 1, Cameroon \\ E-mail: mclairestephane@yahoo.com
}

\section{Chretien Lontsi Djimeli}

Laboratory of Hydrobiology and Environment, University of Yaounde 1, Cameroon E-mail: lontsichretien@yahoo.com

\section{Olive Vivien Noah Ewoti}

Laboratory of Hydrobiology and Environment, University of Yaounde 1, Cameroon E-mail: noahewoti@yahoo.fr

\section{Lucienne Marlyse Moungang}

Laboratory of Hydrobiology and Environment, University of Yaounde 1, Cameroon E-mail: lumou2000@yahoo.fr

\section{Paul Alain Nana}

Laboratory of Hydrobiology and Environment, University of Yaounde 1, Cameroon E-mail: nanpaul4life@yahoo.fr

\section{Antoine Tamsa Arfao}

Microbiology and Biotechnology Laboratory, Saint Jerome Catholic University of Douala, Cameroon. E-mail: tamarfao@yahoo.fr 


\title{
Pierrette Ngo Bahebeck
}

Institut de Recherches Agronomique pour le Devéloppement (IRAD), Yaounde, Cameroon E-mail: ngobahebeck@yahoo.fr

\section{Télesphore Sime-Ngando}

Laboratoire 'Microorganismes: Génome et Environnement', UMR CNRS 6023, Université Clermont Auvergne, Cedex, France

E-mail: Telesphore.sime-ngando@univ-bpclermont.fr

$$
\text { Moïse Nola (Corresponding author) }
$$

Laboratory of Hydrobiology and Environment, University of Yaounde 1, Cameroon

E-mail: moise.nola@yahoo.com

Received: June 13, 2019 Accepted: August 4, 2019 Published: August 7, 2019

Doi: 10.5296/jab.v7i2.14917 URL: https://doi.org/10.5296/jab.v7i2.14917

\begin{abstract}
This study aimed to evaluate in microcosm condition, the survival of Aeromonas hydrophila and Enteropathogenic Escherichia coli (EPEC), in the presence of M. oleiffera aqueous seeds extract at concentrations varying from 1 to $40 \mathrm{~g} / \mathrm{L}$, and under $4{ }^{\circ} \mathrm{C}$ and $23{ }^{\circ} \mathrm{C}$ incubation temperature.It has been noted that cell abundances decrease gradually with the increasing in the seeds extract concentration. However, a marked cells regrowth was sometimes noted. In monospecies cell incubation condition, under $4{ }^{\circ} \mathrm{C}$, the EPEC cells inhibition percentages (CIP) values varied from 52.12 to $99.84 \%$. Those of $A$. hydrophila varied from 13.2 to $96 \%$. The lowest CIPs were noted at the extract concentration $1 \mathrm{~g} / \mathrm{L}$ for EPEC and A. hydrophila. The highest CIP value was registered at 10 and $40 \mathrm{~g} / \mathrm{L}$ for EPEC and at $15 \mathrm{~g} / \mathrm{L}$ for $A$. hydrophila. Under $23{ }^{\circ} \mathrm{C}$ incubation, the EPEC CIPs values varied from 74.04 to $99.9 \%$ and those of $A$. hydrophila varied from 21.2 to $97.8 \%$. For $E$. coli, the lowest and the highest CIP were recorded at the extract concentration $1 \mathrm{~g} / \mathrm{L}$ and $30 \mathrm{~g} / \mathrm{L}$, respectively. In bispecies cells incubation condition, the CIPs were relatively different. These results show the potential exploitation of $M$. oleifera extracts in the microbiological treatment of potable water.
\end{abstract}

Keywords: Aeromonas hydrophila, Aquatic microcosm, Moringa oleifera seeds extract, Escherichia coli 


\section{Introduction}

In most regions around the word, and Africa in particular, he increasing need for water is related to population increase. Unfortunately, potable water is unavailable in most regions around the world. These situations oblige the population to relied on water sources of doubtful quality to satisfy their daily needs which exposes them to microbiological contaminations (UN/WWD, 2006; WHO, 2017a; 2017b). To remedy this situation, several solutions are often recommended. These could be chemical treatment of water, of which the residues have negative effects on health, or filtration and boiling. Some of these methods are laborious and are not always within the reach of the populations. Alternative methods of water disinfection by plant extracts are also proposed (Adriana et al., 2007; Weathers \& Reed 2014). In fact, several studies reported on the antimicrobial properties of plants (Sunda et al., 2008). Statistics show that over $80 \%$ of African and Asian households use medicinal plants to treat themselves (WHO 2002). Hundreds of plant species can be used for therapeutic purposes by the indigenous population (Tamsa Arfao et al., 2013). For example, aqueous extracts of Lantana camara, Cymbogon citratus and Hibiscus rosa-sinensis present a bactericidal effect in aquatic environment (Adriana et al., 2007). In the same way, Eucalyptus microcorys extract showed an inhibiting effect with respect to certain pathogenic germs in aquatic microcosm (Weathers \& Reed, 2014).

The biological treatment of water using seeds of Moringa oleifera could constitute an alternative or integrated solution for the improvement of water quality. It is the most widely cultivated species of the genus Moringa, and its young seed pods and leaves are used as vegetables. All parts of the Moringa tree are edible and have long been consumed by humans (Prabhu et al., 2011; Kuete, 2017). Moringa is used worldwide in traditional medicine, for various health conditions, such as skin infections, anemia, cholera, fever, respiratory disorders, tuberculosis, and intestinal worms (Sairam, 1999; Fuglie, 2001; Mahmood et al., 2010).

Phytochemical analyses have shown that $M$. oleifera is a rich source of potassium, calcium, phosphorous, iron, vitamins $\mathrm{A}$ and $\mathrm{D}$, essential amino acids, as well as known antioxidants, such as $\beta$-carotene, vitamin C, and flavonoids (Bennett et al., 2003; Mbikay, 2012). A wide variety of polyphenols and phenolic acids as well as flavonoids, glucosinolates, and possibly alkaloids are believed to be responsible for the effects of the plant (Ferreira et al., 2008; Stohs \& Hartman, 2015).

Seed powder has been indicated as very effective in clarifying polluted and dirty water from rivers. The floc contained in the seeds or cakes is a basic polypeptide, more specifically a set of active cationic polyelectrolytes with a molecular weight between 6 and $17 \mathrm{KDa}$ (Jahn \& Al Azbaia, 1988). These positively charged polypeptides neutralize colloids in murky waters that are generally negatively charged. In addition, the seeds contain 4L-rhamnosyloxy benzyl isothiocyanates, which could be an antimicrobial agent (Caceres, 1991). The cultivability allows the growth and development of planktonic microorganisms in the water.Little informations related to the impact of the various concentrations of aqueous extract of seeds of M. oleifera on the bacterial growth are available, whether cells are in monospecies or belongs to many species. Also, the impact of environmental temperature on this plant extract activity 
against microorganisms is less documented. Higher environmental temperatures can increase maintenance energy demand and reduce carbon use efficiency (Devêvre \& Horwáth, 2000; Steinweg et al., 2008; Allison et al., 2010). The aim of this study was to assess the impact of aqueous extract of seeds of $M$. oleifera on the cultivability of Aeromonas hydrophila and enteropathogenic Escherichia coli cells in aquatic microcosm, under $4{ }^{\circ} \mathrm{C}$ and $23{ }^{\circ} \mathrm{C}$.

\section{Materials and Methods}

\subsection{Sampling and Preparation of Moringa oleifera Seeds Extract}

The seeds of Moringa oleifera were collected in Maroua (Cameroun, Central Africa). This locality is at latitude $10^{\circ} 35^{\prime} 27^{\prime \prime}$ North, longitude $14^{\circ} 18^{\prime} 57^{\prime \prime}$ East and at $406 \mathrm{~m}$ altitude. This region is characterized by the clayed-sandy and sandy-loamy soils (Martin \& Segalen 1966). The climate is Sudano-Sahelian, characterized by a dry season of 8 to 9 months and a rainy season of 3 to 4 months. Precipitation is fairly low with an annual average of $800 \mathrm{~mm}$ (M'biandoun et al., 2002).

The seeds of Moringa oleifera were harvested, dried at laboratory at a temperature $\left(23 \pm 2{ }^{\circ} \mathrm{C}\right)$ for 2 months and removed from their hull. They were then crushed and the powder was weighed and then mixed with sterile distilled water. The concentrations considered were 1,5 , 10, 15, 20, 30, $40 \mathrm{~g} / \mathrm{L}$.Homogenized extracts was left to settle for 5 minutes. The $\mathrm{pH}$ solutions were adjusted at 7 using $\mathrm{NaOH}$ and $\mathrm{HCl}$ solutions and the supernatant filtered using successively whatman filter paper firstly, nitrocellulose membrane of $0.45 \mu \mathrm{m}$ porosity secondly and the Millex membrane of $0.22 \mu \mathrm{m}$ porosity thirdly (Rodier, 2009; APHA, 2012).

\subsection{Bacteria Strains and Cell'S Suspensions}

The bacterial cells considered were enteropathogenic Escherichia coli and Aeromonas hydrophila strains. They were selected because of their high importance and strong occurrence as indicator of microbiological quality of water used for consumption (Lacasse, 2004; WHO, 2011). The enteropathogenic E. coli strain was provided by the Laboratory of Microbiology and Environment of Centre Pasteur (Cameroon, Central Africa). A. hydrophila strain was isolated from groundwater in Yaounde using membrane filtration method and Ampicillin Dextrin agar culture medium. Both strains cells were then identified using biochemical criteria (Holt et al., 2000). Cells were then stored in glycerol at $-15{ }^{\circ} \mathrm{C}$ for later use.2.3 Experimental Protocol

Experiments were done in 2 series. The first was done using cells of one bacterial species. The second was done using cells of both bacterial species under consideration. At each extract concentration for each series of experiment, 2 groups of glass flasks A and B were used. With each group being made up of 3 glass flasks.

For the first series, prior to the experiments, a frozen vial containing each cells strain was defrosted at room temperature. The culture $(300 \mu \mathrm{L})$ was then transferred into $10 \mathrm{~mL}$ of nutrient broth (Oxford) and incubated at $37^{\circ} \mathrm{C}$ for 24 hours. Cells were then collected by centrifugation $\left(8000 \mathrm{rpm}\right.$ for $10 \mathrm{~min}$ at $10{ }^{\circ} \mathrm{C}$ ) and washed twice with sterile $\mathrm{NaCl}(8.5 \mathrm{~g} / \mathrm{L})$ solution. The sediment was then diluted in $10 \mathrm{~mL}$ of sterile $\mathrm{NaCl}$ solution. Homogenized bacterial suspension was adjusted to a density of $0.5 \mathrm{Mac}$ Farland $\left(\mathrm{BaCl}_{2}\right.$ and of $\left.\mathrm{H}_{2} \mathrm{SO}_{4} 1 \%\right)$. Bacteria concentration of the original suspension was about $10^{8} \mathrm{CFU} / \mathrm{ml}$. After dilution, $1 \mathrm{ml}$ of 
the cells suspension was added to the glass flasks containing $100 \mathrm{ml}$ of different concentrations of seeds extract solutions filtered as indicated above. The really concentration that the control contain is $2 \times 10^{8} \mathrm{CFU} / \mathrm{ml}$.

The samples were then incubated for 6hours. The incubation period of $6 \mathrm{~h}$ was considered based on the studies carried out by Weathers and Reed (2014), which indicated that after $3 \mathrm{~h}$ contact between a bacterial cell and the plant extract, a metabolic interactions result is observed. Two temperature incubation $4{ }^{\circ} \mathrm{C}$ and $23{ }^{\circ} \mathrm{C}$ were chosen. The temperature of $23{ }^{\circ} \mathrm{C}$ was chosen to simulate the ambient temperature in most households in the equatorial region, and $4{ }^{\circ} \mathrm{C}$ is usually used to incubate or store bacterial strains. The glass flasks of group A were incubated at $4{ }^{\circ} \mathrm{C}$, and those of group B were incubated at $23{ }^{\circ} \mathrm{C}$.

Analyses were carried out using Endo and Ampicillin Dextrin agar culture media respectively for $E$. coli and A. hydrophila. Petri dishes were then incubated at $44^{\circ} \mathrm{C}$ and $37^{\circ} \mathrm{C}$ respectively for 24 hours (Marchal et al., 1991; APHA, 2012), and the colony forming, units (CFUs) were then counted. The bacterial density was expressed in Colonies Forming Units (CFU)/100 mL of sample.

For the second series of experiments, bacteria concentration of original suspension of about $10^{8} \mathrm{CFU} / \mathrm{mL}$ for each cells species. $100 \mu \mathrm{L}$ of $E$. coli and the same of $A$. hydrophila were mixed. After dilution, $100 \mu \mathrm{L}$ of the cells suspension was added to the tubes containing different concentrations $(1,5,10,15,20,30,40 \mathrm{~g} / \mathrm{L})$ of seeds extract solutions filtered as indicated above following the same protocol. The experiment was performed in triplicate.

\subsection{Data Analysis}

The variations of cell abundances $\left(\mathrm{N}_{\mathrm{n}}\right)$ as well as cells inhibition percentages (CIP) after $6 \mathrm{~h}$ according to the concentration of the extract of Moringa oleifera at each temperature were illustrated by histograms. The CIP were calculated according to the following formula (Weathers \& Reed, 2014; Edima et al., 2010):

$$
C I P=\left(\frac{N_{0}-N_{n}}{N_{0}}\right) \times 100
$$

$\mathrm{N}_{0}=$ number of CFU/100 mL before adding the seeds extract solution; $\mathrm{N}_{\mathrm{n}}=$ number of $\mathrm{CFU} / 100 \mathrm{~mL}$ after incubation in a given condition in the seeds extract solution of $M$. oleifera. The Spearman correlation test " $r$ " has been used to assess the relationship between the considered parameters. The comparison between bacteria abundances were carried out using the test $\mathrm{H}$ of Kruskal-Wallis and $\mathrm{U}$ of Mann Withney. This analysis was done using SPSS version 16.0 program.

\section{Results and Discussion}

\subsection{Temporal Variation of Cell Abundances}

When enteropathogenic $E$. coli cells were the only cells species in solutions, their abundance in different extract concentrations varied from $500 \times 10^{3}$ to $0.92 \times 10^{3} \mathrm{CFU} / 100 \mathrm{~mL}$. At $4{ }^{\circ} \mathrm{C}$, it varied from $224.48 \times 10^{3}$ to $3.58 \times 10^{3} \mathrm{CFU} / 100 \mathrm{~mL}$ (Figure 1). The lowest abundance was registered at the concentration $10 \mathrm{~g} / \mathrm{L}$, and the highest at $1 \mathrm{~g} / \mathrm{L}$. At $23{ }^{\circ} \mathrm{C}$, it varied from $129.7 \times 10^{3}$ to $0.92 \times 10^{3} \mathrm{CFU} / 100 \mathrm{~mL}$ the lowest abundance was registered at the concentration 
$30 \mathrm{~g} / \mathrm{L}$, and the highest at $1 \mathrm{~g} / \mathrm{L}$. Cells concentrations in the control (solution without seeds extract) was $500 \times 10^{3} \mathrm{CFU} / 100 \mathrm{~mL}$ at $23{ }^{\circ} \mathrm{C}$ and $4{ }^{\circ} \mathrm{C}$, respectively.

When $A$. hydrophila cells were the only cells species in solutions, their abundance varied from $500 \times 10^{3}$ to $11 \times 10^{3} \mathrm{CFU} / 100 \mathrm{~mL}$. At $4^{\circ} \mathrm{C}$, it varied from $434 \times 10^{3}$ to $20 \times 10^{3} \mathrm{CFU} / 100 \mathrm{~mL}$ (Figure 1). The lowest abundance was registered at the concentration $15 \mathrm{~g} / \mathrm{L}$, and the highest at $1 \mathrm{~g} / \mathrm{L}$. At $23{ }^{\circ} \mathrm{C}$, it varied from $394 \times 10^{3}$ to $11 \times 10^{3} \mathrm{CFU} / 100 \mathrm{~mL}$ the lowest abundance was registered at the concentration $15 \mathrm{~g} / \mathrm{L}$, and the highest at $5 \mathrm{~g} / \mathrm{L}$. Cells concentrations in the control (solution without seeds extract) were $500 \times 10^{3} \mathrm{CFU} / 100 \mathrm{~mL}$.

In the presence of $A$. hydrophila and enteropathogenic $E$. coli cells, it was observed in most cases that cell abundances decrease gradually with increasing seeds extract concentration. However, a slight regrowth of $E$. coli was perceptible at the extract concentration $40 \mathrm{~g} / \mathrm{L}$ (Figure 1). It was also noted at each extract concentration in each of the incubation temperature, that $E$. coli cells abundances as well as those of $A$. hydrophila were relatively higher at $4{ }^{\circ} \mathrm{C}$ compared to those recorded at $23{ }^{\circ} \mathrm{C}$ (Figure 1).

When cells of the 2 bacterial species were present simultaneously, the abundance of $E$. coli under $4{ }^{\circ} \mathrm{C}$ varied from $179.4 \times 10^{3}$ to $0 \mathrm{CFU} / 100 \mathrm{~mL}$. That of $A$. hydrophila under $23^{\circ} \mathrm{C}$ varied from $131.6 \times 10^{3}$ to $0 \mathrm{CFU} / 100 \mathrm{~mL}$ (Figure 1). The lowest abundance was registered at the concentration $40 \mathrm{~g} / \mathrm{L}$ for both $E$. coli and A. hydrophila. The highest abundances were recorded at $5 \mathrm{~g} / \mathrm{L}$ and $1 \mathrm{~g} / \mathrm{L}$ for $E$. coli and $A$. hydrophila, respectively (Figure 1 ). At $23{ }^{\circ} \mathrm{C}$, the lowest abundance was registered at the concentration $40 \mathrm{~g} / \mathrm{L}$ for $E$. coli and $A$. hydrophila. The highest abundances were recorded at $1 \mathrm{~g} / \mathrm{L}$ for both $E$. coli and $A$. hydrophila (Figure 1). In most cases, cell abundances decreased gradually with increasing seeds extract concentration. However, a marked regrowth of $E$. coli was noted at the extract concentration of $20 \mathrm{~g} / \mathrm{L}$. In contrast with the case when cells belonging to one species were used, E. coli cells abundances as well as those of A. hydrophila were sometimes relatively lower at $4{ }^{\circ} \mathrm{C}$ compared to those recorded at $23{ }^{\circ} \mathrm{C}$ (Figure 1). 


\section{MInstitute Macrothink $^{m}$}
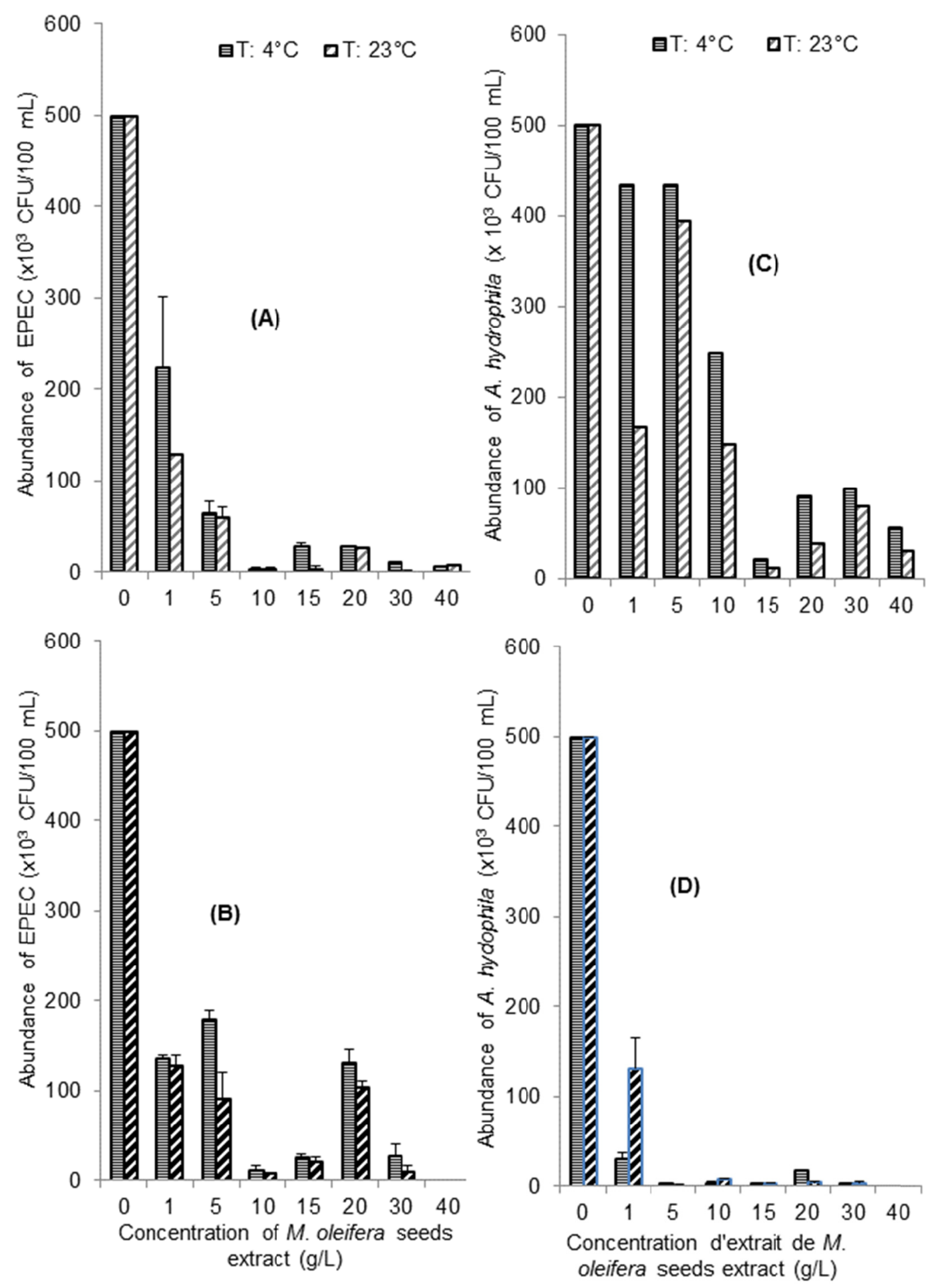

Figure 1. Variation in E. coli abundance with respect to the concentration of seeds extract in monospecies cells incubation condition (A) and bispecies cells incubation condition (B), and that of A. hydrophila in monospecies cells incubation condition (C) and bispecies cells incubation condition (D) 


\subsection{Cells Inhibition Percentages (CIP)}

The cells inhibition percentages (CIP) have been evaluated under various considered parameters (concentration of the aqueous extract, incubation temperature, number of cells species present). Similarly, the percentage inhibition cells (CIP) make it possible to evaluate the impact of the aqueous extract of these seeds on the abundance data of the two bacterial species studied.

At $4{ }^{\circ} \mathrm{C}$ when one species of cell was used, the E. coli CIP values varied from 55.12 to $99.84 \%$. Those of $A$. hydrophila varied from 13.2 to $96 \%$ (Figure 2). The lowest CIP value was recorded at the extract concentration $1 \mathrm{~g} / \mathrm{L}$ for $E$. coli and $A$. hydrophila. The highest CIP value was registered at the extract concentration 10 and $40 \mathrm{~g} / \mathrm{L}$ for $E$. coli and $15 \mathrm{~g} / \mathrm{L}$ for $A$. hydrophila. Under $23{ }^{\circ} \mathrm{C}$ incubation, the $E$. coli CIP values varied from 74.04 to $99.9 \%$ and those of $A$. hydrophila varied from 21.2 to $97.8 \%$. For E. coli, the lowest and the highest CIP values were recorded at the extract concentration $1 \mathrm{~g} / \mathrm{L}$ and $30 \mathrm{~g} / \mathrm{L}$ respectively. For $A$. hydrophila, the lowest $\mathrm{CIP}$ value was registered at $5 \mathrm{~g} / \mathrm{L}$ whereas the highest was recorded at $15 \mathrm{~g} / \mathrm{L}$ (Figure 2).

When both cells species were simultaneously present and at $4{ }^{\circ} \mathrm{C}$, the lowest $(64.12 \%)$ and the highest (100\%) CIP values for $E$. coli were recorded respectively at the extract concentration of $5 \mathrm{~g} / \mathrm{L}$ and $40 \mathrm{~g} / \mathrm{L}$. For $A$. hydrophila, the lowest (93.9\%) CIP value was registered at $1 \mathrm{~g} / \mathrm{L}$ whereas the highest $(100 \%)$ was recorded at $40 \mathrm{~g} / \mathrm{L}$. At $23{ }^{\circ} \mathrm{C}$, the lowest CIP values for $E$. coli and $A$. hydrophila were $74.48 \%$ and $73.8 \%$ respectively, all of them at $1 \mathrm{~g} / \mathrm{L}$. The highest was $100 \%$ for both cells species (Figure 2). 

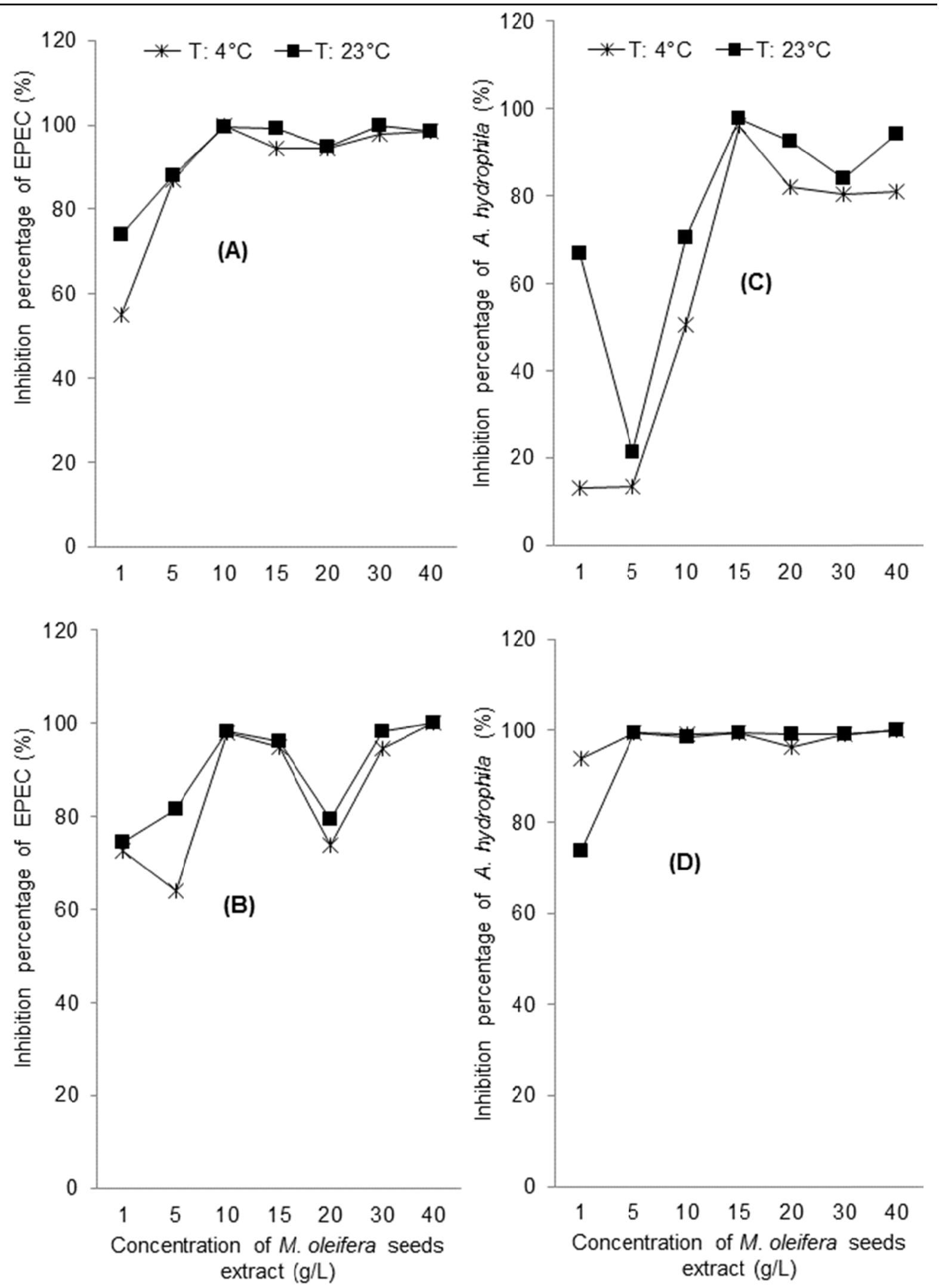

Figure 2. Cells inhibition percentages of $E$. coli cells in monospecies cells incubation condition (A) and bispecies cells incubation condition (B), and of $A$. hydrophila cells in monospecies cells incubation condition (C) and bispecies cells incubation condition (D) 


\subsection{Relations Among the Considered Parameters}

Spearman's correlation test shows that an increase in incubation temperature is concomitant with a significant $(\mathrm{P}<0.05)$ decrease in $E$. coli abundance when it is the only cell species present and when the concentrations of seeds extracts are 5, 10 and $40 \mathrm{~g} / \mathrm{L}$ (Table 1). When $A$. hydrophila cells are present alone, the increase in incubation temperature is significantly concomitant $(\mathrm{P}<0.05)$ with the decrease in cell abundance at the concentration of $10 \mathrm{~g} / \mathrm{L}$ of the seeds extract (Table 1). When the two-cell species are present simultaneously, the increase in incubation temperature appears to be significantly $(\mathrm{P}<0.05)$ concomitant with the decrease in the cells abundances at concentrations at 1 and $30 \mathrm{~g} / \mathrm{L}$ for $E$. coli and at the concentration $1 \mathrm{~g} / \mathrm{L}$ only, for A. hydrophila (Table 1).

Table 1. Spearman correlation coefficients between the cells abundances and the incubation temperature at each seeds extract concentration, in monospecies and bispecies cells incubation conditions after 6 hours

\begin{tabular}{|c|c|c|c|c|c|c|c|c|}
\hline \multicolumn{2}{|c|}{$\begin{array}{l}\text { Cells species considered } \\
\text { and incubation condition }\end{array}$} & \multicolumn{7}{|c|}{ Seeds extract concentration $(\mathrm{g} / \mathrm{L})$} \\
\hline $\begin{array}{l}\text { Cells } \\
\text { species }\end{array}$ & $\begin{array}{c}\text { Cells } \\
\text { incubation } \\
\text { condition }\end{array}$ & 1 & 5 & 10 & 15 & 20 & 30 & 40 \\
\hline \multirow{2}{*}{ E. coli } & $\begin{array}{l}\text { Monospecies } \\
\text { cells }\end{array}$ & -0.000 & $-0.909 *$ & $-0.864 *$ & -0.682 & -0.000 & -0.441 & $-0.864 *$ \\
\hline & $\begin{array}{l}\text { Bispecies } \\
\text { cells }\end{array}$ & $-1.000^{*}$ & -0.400 & -0.800 & -0.600 & -0.400 & $-1.000^{*}$ & / \\
\hline \multirow{2}{*}{$\begin{array}{l}\text { A. } \\
\text { hydrophila }\end{array}$} & $\begin{array}{l}\text { Monospecies } \\
\text { cells }\end{array}$ & -0.091 & -0.455 & $-0.864 *$ & -0.375 & -0.088 & -0.530 & -0.727 \\
\hline & $\begin{array}{l}\text { Bispecies } \\
\text { cells }\end{array}$ & $-1.000^{*}$ & -0.400 & -0.800 & -0.949 & -0.600 & -0.400 & / \\
\hline
\end{tabular}

$*: \mathrm{P} \leq 0.05 ; \mathrm{df}($ degree of freedom $)=5$ (number of observations)

The Table 2 shows that at all incubation temperatures, an increase in seeds extract concentration significantly decrease $(\mathrm{P}<0.05)$ the abundance of E. coli and A. hydrophila in the solutions when cells are of monospecies. When cells belong to the two-bacterial species considered, the same observation was made except the abundance of E. coli when solutions were incubated at $4{ }^{\circ} \mathrm{C}$ (Table 2). 
Table 2. Spearman correlation coefficients between the cells abundances and the seeds extract concentrations at each incubation temperature, after 6 hours in monospecies and bispecies cells incubation conditions

\begin{tabular}{lccc}
\hline \multicolumn{2}{c}{ Cells species considered and incubation condition } & \multicolumn{2}{c}{ Incubation temperature } \\
\hline $\begin{array}{l}\text { Cells species } \\
\text { considered }\end{array}$ & Cells incubation condition & $4{ }^{\circ} \mathrm{C}$ & $23{ }^{\circ} \mathrm{C}$ \\
E. coli & Monospecies cells & $-0.614^{* *}$ & $-0.547^{* *}$ \\
& Bispecies cells & -0.402 & $-0.484^{*}$ \\
A. hydrophila & Monospecies cells & $-0.710^{* *}$ & $-0.744^{* *}$ \\
& Bispecies cells & $-0.867^{* *}$ & $-0.894^{* *}$ \\
\hline
\end{tabular}

$*: \mathrm{P} \leq 0.05 ; * *: \mathrm{P} \leq 0.01 ; \mathrm{df}($ degree of freedom $)=20$ (number of observations)

A comparison between the cells abundances recorded at $4{ }^{\circ} \mathrm{C}$ with those recorded at $23{ }^{\circ} \mathrm{C}$ shows that, in the monospecies cellular condition, the abundances of E. coli differed significantly $(\mathrm{P} \geq 0.05)$ from each other at each of the concentrations of seeds extract used (Table 3).

Table 3. The "P" values indicating the degrees of significance of the difference related to the comparison of the cells abundances registered between $4{ }^{\circ} \mathrm{C}$ and $23{ }^{\circ} \mathrm{C}$ incubation, at each seeds extract concentration after 6 hours in monospecies and bispecies cells incubation conditions

\begin{tabular}{|c|c|c|c|c|c|c|c|c|}
\hline \multicolumn{2}{|c|}{$\begin{array}{l}\text { Cells species considered } \\
\text { and incubation condition }\end{array}$} & \multicolumn{7}{|c|}{ Seeds extract concentrations $(\mathrm{g} / \mathrm{L})$} \\
\hline $\begin{array}{l}\text { Cells } \\
\text { species } \\
\text { considered }\end{array}$ & $\begin{array}{c}\text { Cells } \\
\text { incubation } \\
\text { condition }\end{array}$ & 1 & 5 & 10 & 15 & 20 & 30 & 40 \\
\hline \multirow{2}{*}{ E. coli } & $\begin{array}{l}\text { Monospecies } \\
\text { cells }\end{array}$ & $0.043^{*}$ & $0.513^{*}$ & $0.513^{*}$ & $0.043^{*}$ & $0.043^{*}$ & $0.043^{*}$ & $0.043^{*}$ \\
\hline & $\begin{array}{l}\text { Bispecies } \\
\text { cells }\end{array}$ & 0.439 & 0.121 & $1.000^{*}$ & 0.439 & 0.121 & 0.439 & $1.000^{*}$ \\
\hline \multirow{2}{*}{$\begin{array}{l}\text { A. hydro- } \\
\text { phila }\end{array}$} & $\begin{array}{l}\text { Monospecies } \\
\text { cells }\end{array}$ & $0.043^{*}$ & 0.589 & 0.513 & $0.487 *$ & $0.043^{*}$ & 0.500 & $0.043^{*}$ \\
\hline & $\begin{array}{c}\text { Bispecies } \\
\text { cells }\end{array}$ & 0.121 & 0.439 & 0,121 & 0.221 & 0.121 & $1.000 *$ & $1.000^{*}$ \\
\hline
\end{tabular}

$*: \mathrm{P} \geq 0.05 ; \mathrm{df}($ degree of freedom $)=40$ (number of observations).

The abundances of $A$. hydrophila at both incubation temperatures significantly differed $(\mathrm{P} \geq$ 0.05 ) from each other only at concentrations 1, 15, 20 and $40 \mathrm{~g} / \mathrm{L}$ of seeds extract. When the 
two bacterial species were present simultaneously, the abundances of the E. coli cells recorded at $4{ }^{\circ} \mathrm{C}$ significantly differed $(\mathrm{P} \geq 0.05)$ from those recorded at $23{ }^{\circ} \mathrm{C}$ and concentrations 10 and $40 \mathrm{~g} / \mathrm{L}$ of seeds extract. The A. hydrophila cells abundance significantly differed $(\mathrm{P} \geq 0.05)$ between the two temperatures only at concentrations 30 and $40 \mathrm{~g} / \mathrm{L}$ of extract (Table 3 ).

It was also noted that the recorded abundances of $E$. coli significantly differed from one extract concentration to another $(\mathrm{P}<0.05)$, at the incubation temperature of $4{ }^{\circ} \mathrm{C}$ as well as at $23^{\circ} \mathrm{C}$, when the cells present belongs to a single species. The same observation was made for A. hydrophila (Table 4). On the other hand, when the two bacterial species are simultaneously present, the abundances of the recorded cells do not differ significantly ( $P>0.05$ ) from one extract concentration to another (Table 4).

Table 4. The "P" values indicating the degree of significance of the difference related to the comparison of the cells abundances registered among the seeds extract concentrations after 6 hours, in monospecies and bispecies cells incubation conditions, at $4{ }^{\circ} \mathrm{C}$ and $23{ }^{\circ} \mathrm{C}$

\begin{tabular}{lccc}
\hline Cells species considered and incubation condition & \multicolumn{2}{c}{ Incubation temperatures } \\
\hline $\begin{array}{l}\text { Cells species } \\
\text { considered }\end{array}$ & Cells incubation condition & $4{ }^{\circ} \mathrm{C}$ & $23{ }^{\circ} \mathrm{C}$ \\
E. coli & Monospecies cells & $0.004^{*}$ & $0.004^{*}$ \\
& Bispecies cells & 0,060 & 0.067 \\
A. hydrophila & Monospecies cells & $0.005^{*}$ & $0.004^{*}$ \\
& Bispecies cells & 0.070 & 0.070 \\
\hline
\end{tabular}

$*: \mathrm{P} \leq 0.05 ; \mathrm{df}($ degree of freedom $)=19$ (number of observations).

\subsection{Discussion}

The bacteria decay curves obtained show that the Moringa oleifera extract can be used as a natural, green alternative for effectiveness water treatment. The antibacterial activity of Moringa oleifera seed extract would be due to the presence of a short, cationic protein within the seed. This protein, commonly known as the Moringa oleifera cationic protein (MOCP), has been shown to cause bacterial cell damage through rapid flocculation and fusion of their inner and outer membranes (Shebek et al., 2015). This protein would inhibit bacterial growth and that stronger concentrations facilitate higher bactericidal properties. However, this activity is dependent on the bacterial load, and increased bacterial concentration would require a larger dose or a stronger concentration of the seed extract.

The $M$. oleifera extract inhibitory effect against bacterial cell would be linked to the phytochemicals. Working on the structure-function characterization and optimization of a plant-derived antibacterial peptide, Suarez et al. (2008) noted that one of the seed peptides mediates both the sedimentation of suspended bacterial cells and a direct bactericidal activity, raising the possibility that the two activities might be related. In addition, Shebek et al. (2015) 
indicated that a cationic protein isolated from the seeds of the Moringa oleifera tree has an important antibacterial activity. Its dominant mechanism of antimicrobial activity is membrane fusion. Its activity includes adsorption, stalk formation, and fusion between membranes.

Temperature is one of the explanatory parameters of changes in bacterial abundances. It indirectly influences bacterial productivity by modifying the physical and chemical properties of their environment. In this study, temperature appears as an important factor involved in the cellular inhibition. The incubation temperature increases the effectiveness of the aqueous extract of Moringa oleifera seeds, the inhibition being considerable at the psychrophilic temperature (Mauguin et al., 2004).

It is observed that an increase in the concentration of seeds extracts significantly improved the seeds extract inhibitory activity (Table 2 ). The seeds have been indicated as containing calcium, magnesium, phosphorus, copper, vitamins (A, B and E), and are also rich in organic elements (Hans \& Bindanda, 2003). These different secondary metabolites in excess could accumulate in the bacterial cell walls and become toxic. Bacteria inhibition could also be due to the presence of $\alpha$-L-rhamnosyloxy benzyl isothiocyanate molecules which are found in the seeds and whose antibacterial and antifongic properties have been described (Caceres, 1991). These molecules are soluble and are positively charged. They can easily cross the bacterial membrane to bind to cation proteins negatively charged on the cells membrane surface and support their inhibition (Thevissen et al., 1996).

Jahn (1988) reported that water disinfection by Moringa seeds requires relatively high doses of $200 \mathrm{~g} / \mathrm{L}$ of extract to have a germicidal effect. In this study, from $1 \mathrm{~g} / \mathrm{L}$ to $40 \mathrm{~g} / \mathrm{L}$ of extract, the bacterial inhibitions varying from $55.12 \%$ to $99.9 \%$ for $E$. coli, and from $13.2 \%$ to $97.8 \%$ for $A$. hydrophila. This suggest that the environment, as well as the genetic characteristics of the bacteria or other abiotic properties of the water used, could affect the activity of the seeds constituents and other parts of the plant (roots and flowers). It has also been indicated that the content of chemical components varies with Moringa species (Jahn, 1988).

The antimicrobial activity of Moringa extracts was previously attributed to plant-produced benzyl isothiocynate derivatives (Eilert et al., 1981). Suarez et al. (2003) showed that at least part of the antimicrobial activity of Moringa seeds extract may stem from Flo-like polypeptides. According to Zasloff (2002), they act by forming essential enzymes, leading to cell deaths.

Chuang et al., (2007) has studied the mode of attack of Moringa oleifera seeds extract on fungus. The results showed that the cytoplasmic membrane of the fungal cell was ruptured and the intercellular components were seriously damaged after treatment with M. oleifera seed crude extract. However, the intercellular components did not leak out. Based on previous studies of cell lysis pathways of antimicrobial peptides on bacteria (Chan et al., 1998; Chen et al., 2003), this indicated that extracted compounds interacted with the lipid bilayers in membranes leading to the separation of the two membranes (outer and inner). Subsequently, water dips in to the cell, which causes cell to swell more and leads to death.

It has been noted that incubation temperature relatively impacts the seeds extract activity. In bispecies cells incubation condition, the high percentages of inhibition observed at $4{ }^{\circ} \mathrm{C}$ and 
$23^{\circ} \mathrm{C}$ in the present study may be explained by the fact that these temperatures accelerate bacterial metabolism, with toxic products being metabolized. Lessard and Sieburth (1983) suggested that low temperatures can lead to better survival by the fact that the metabolism of mesophilic bacteria is very slow, the toxic products present at the same time as the high concentrations of nutrients are only very slowly metabolized. The biochemical reactions underlying cellular metabolism depend on the activities of the enzymes, which are themselves largely influenced by the environmental temperature (Regnault, 2002; Mauguin et al., 2004).

In monospecies cell incubation condition as well as in bispecies, a slight cells regrowth was sometime noted. It is known that bacterial cells are made up of a variety of molecules, some of which may be nutritious (Holt et al., 2000; Mainil, 2005; McInerney et al., 2008). During seeds extract activity, the cell inhibition followed by the degradation of some cells could lead to the release into the medium of cellular compounds. Surviving cells would probably use some of these energetic constituents of these compounds for the time of their survival. In bispecies cell incubation condition, these slight cells regrowth could also be due to the metabolism of the cells of both species. This phenomenon is usually known as a synthrophy. In this form of association, the catabolism products of one would become a source of carbon and energy for the other (McInerney et al., 2008). This form of mutualism has been mentioned between Enterobacteriaceae bacteria and lactic acid bacteria by other authors (Jorgensen et al., 2004). In addition, some molecules from the extracts can be a source of nutrients and allow the cell regrowth, as it was indicated that a seed of $M$. oleifera contains organic compounds (Ferreira \& Janick, 1996). The doubling of the bacterial population could contribute to a rapid depletion of nutrient molecules and an accumulation of metabolic waste. This would lead to the slight aspect of the cells regrowth noted.

\section{Conclusion}

This study showed a significant effect of bacterial inhibition of the aqueous extract of seeds of Moringa oleifera on the two bacteria species studied. Cell abundances decreases gradually with an increased seeds extract concentration. However, a marked regrowth of E. coli was sometimes noted. When cells belonging to one species were used, E. coli cells abundances as well as those of $A$. hydrophila were sometimes relatively lower at $4{ }^{\circ} \mathrm{C}$ compared to those recorded at $23{ }^{\circ} \mathrm{C}$. The seeds extract concentrations also plays an important role in this inhibition.

\section{Acknowledgement}

We extend our thanks to the authorities of the Laboratory of Microbiology and Environment of Centre Pasteur of Cameroon, the University of Yaoundel (Cameroon) and the University Clermont Auvergne (France), for their logistic and material contributions.

\section{References}

Adriana, B., Almodovar, A. N. M., Pereira, C. T., \& Mariangla, T. A. (2007). Antimicrobial efficacy of Curcuma zedoaria extract assessed by linear regression compared with commercial mouth rinses. Brazilian J. Microbiol, 38, 440-445. https://doi.org/10.1590/S1517 $-83822007000300011$ 
Allison, S. D., Wallenstein, M. D., \& Bradford, M. A. (2010). Soil carbon response to warming dependent on microbial physiology. Nature Geoscience, 3, 336-340. https://doi.org/10.1038/ngeo846

APHA (American Public Health Association). (2012). Standard methods for the examination of water and waste water (22th ed.). Washington DC.

Bennett, R. N., Mellon, F. A., Foidl, N., Pratt, J. H., Dupont, M. S., \& Perkins, L. (2003) Profiling glucosinolates and phenolics in vegetative and reproductive tissues of the multi-purpose trees Moringa oleifera L. (horseradish tree) and Moringa stenopetala L. J. Agric. Food Chem, 51(12), 3546-3553. https://doi.org/10.1021/jf0211480

Caceres, A. (1991). Pharmacological properties of Moringa oleifera: Effect of seed extracts in the treatment of experimental pydermia. Fitoterapia, 62, 449-454

Chan, S. C., Yau, W. L., Wang, W., Smith, D., Sheu, F. S., \& Chen, H. M. (1998). Microscopic observations of the different morphological changes by the anti-bacterial peptides on Klebsiella pneumoniae and HL-60 leukemia cells. J. Peptide Science, 4, 413-425. https://doi.org/10.1002/(SICI)1099-1387(199811)4:7\%3C413::AID-PSC160\%3E3.0.CO;2-W

Chen, X.-L., Zhang, Y.-Z., Gao, P.-J., \& Luan, X.-W. (2003). Two different proteases produced by a deep-sea psychrotrophic bacterial strain, Pseudoaltermonas SM9913. Mar. Biol, 143, 989-993. https://doi.org/10.1007/s00227-003-1128-2

Chuang, P.-H. Chi-Wei, L., Jia-Ying, C., Murugan, M., Bor-Jinn, S., \& Hueih-Min, C. (2007). Anti-fungal activity of crude extracts and essential oil of Moringa oleifera Lam. Bioresource Technology, 98, 232-236. https://doi.org/10.1016/j.biortech.2005.11.003

Devêvre, O. C., \& Horwáth, W. R. (2000). Decomposition of rice straw and microbial carbon use efficiency under different soil temperatures and moistures. Soil Biol. Biochemy, 32, 1773-1785. https://doi.org/10.1016/S0038-0717(00)00096-1

Edima, H. Tatsadjieu, L., Mbofung, C., \& Etoa, F. X. (2010). Anti-bacterial profile of some beers and their effect on some selected pathogens. Afr. J. Biotechnol, 5938-5945.

Eilert, U., Wolters, B., \& Nahrstedt, A. (1981). The antibiotic principle of Moringa Oleifera and Moringa Stenopetala. Plant Medica, 42, 55-61. https://doi.org/10.1055/s-2007-971546

Ferreira, J. F. S., \& Janick, J. (1996). Distribution of Artemisinin in Artemisia annua (pp. 579-584). In New Crops Arlington, VA.

Ferreira, P. M. P., Farias, D. F., Oliveira, J. T. A., \& Carvalho, A. F. U. (2008). Moringa oleifera: bioactive compounds and nutritional potential. Rev. Nutr. Campinas, 21, 431-437. https://doi.org/10.1590/S1415-52732008000400007

Fuglie, L. J. (2001). The Miracle Tree: Moringa oleifera -Natural Nutrition for the Tropics. Church World Service, Dakar, Senegal

Hans, M., \& Bindanda, M. (2003). Tropical Natural Medicine: How to Heal With Tropical Plants. Schafweide, Winnenden. 
Holt, J. N. Krieg, P., Sneath, J., \& Staley, W. S. (2000). Bergey Manual of Determinative Bacteriology (9th ed.). Lipponcott Williams and Wilkins, Philadelphia.

Jahn \& Al, A. S. (1988). Using moringa seeds as coagulant in developing countries. Journal AWWA, 6, 43-50. https://doi.org/10.1002/j.1551-8833.1988.tb03052.x

Jorgensen, P. R., Larry, D. M., \& Kistrup, J. (2004). Aquifer Vulnerability to Pesticide Migration Through Till Aquitards. Ground Water, 5, 841-855. https://doi.org/10.1111/j.17456584.2004.t01-3-.x

Kuete, V. (2017). Medicinal spices and vegetables from Africa. Therapeutic potential against metabolic, inflammatory, infectious and systemic diseases. Academic Press, London.

Lacasse, D. (2004). Introduction to food microbiology. Québec.

Lessard, E., \& Siebuth, J. (1983). Survival of natural sewage populations of enteric bacteria in diffusion and bath chambers in the marine environment. Applied and Environmental Microbiology, 45, 950-959

Mahmood, K. T., Mugal, T., \& U1 Haq, I. (2010). Moringa oleifera: a natural gift-a review. J. Pharm. Sci. Res, 2, 775-781

Mainil, J. (2005). Génétique et régulation de la virulence bactérienne: Vers la version moléculaire des postulats de Koch. Annales de Médecine Vétérinaire, 149, 24-32

Marchal, N., Bourdon, J. L., \& Richard, C. (1991). Milieux de culture pour isolement et identification des bactéries. Paris.

Martin, D., \& Segalen, P. (1966). Carte pédologique du Cameroum oriental: Notice explicative. Yaounde.

Mauguin, G., Delion, N., \& Corsin, P. (2004). La température de l'eau, un paramètre important pour la production d'eau destinée à la consommation humaine. L'eau, l'Industrie, les Nuisances, 27, 23-29.

M'Biandoun, M., Guibert, H., \& Olina, J.-P. (2002). Caractérisation du climat dans quatre terroirs en région soudano-sahélienne du Nord-Cameroun et conséquences pour l'agriculture. Actes du colloque sur «Savanes africaines: des espaces en mutation, des acteurs face à de nouveaux défis», mai 2002, Maroua, Cameroun.

Mbikay, M. (2012). Therapeutic potential of Moringa oleifera leaves in chronic hyperglycemia and dyslipidemia: A review. Front. Pharmacol, 3, 24. https://doi.org/10.3389/ fphar.2012.00024

McInern, M. J., Struchtemeyer, C. G., Sieber, J., Mouttaki, H., Stams, A. J., Schink, B., Rohlin, L., \& Gunsalus, R. P. (2008). Physiology, ecology, phylogeny, and genomics of microorganisms capable of syntrophic metabolism. Annals of the New York Academy of Sciences, 1125, 58-72. https://doi.org/10.1196/annals.1419.005

Prabhu, K., Murugan, K., Nareshkumar, A., Ramasubramanian, N., \& Bragadeeswaran, S. 
(2011). Larvicidal and repellent potential of Moringa oleifera against malarial vector, Anopheles stephensi Liston (Insecta: Diptera: Culicidae). Asian Pac. J. Trop. Biomed, 1, 124-129. https://doi.org/10.1016/S2221-1691(11)60009-9

Regnault, J. (2002). Eléments de microbiologie et d'immunologie (p. 601).

Rodier, J. (2009). L'analyse de l'eau (9th ed.). Dunod, Paris.

Sairam, T. V. (1999). Home Remedies, vol II: A Handbook of Herbal Cures for Commons Ailments. Penguin, New Delhi, India.

Shebek, K., Schantz, A. B., Sines, I., Lauser, K., Velegol, S., \& Kumar, M. (2015). The flocculating cationic polypetide from Moringa oleifera seeds damages bacterial cell membranes by causing membrane fusion. Langmuir, 31, 4496-4502. https://doi.org/10.1021/acs.langmuir.5b00015

Steinweg, J. M., Plante, A. F., Conant, R. T., Paul, E. A., \& Tanaka, D. L. (2008). Patterns of substrate utilization during long-term incubations at different temperatures. Soil Biol. Biochem, 40, 2722-2728. https://doi.org/10.1016/j.soilbio.2008.07.002

Stohs, S. J., \& Hartman, M. J. (2015). Review of the safety and efficacy of Moringa oleifera. Phytother. Res, 29, 796-804. https://doi.org/10.1002/ptr.5325

Suarez, M., Entenza, J. M., Doerries, C., Meyer, E., Bourquin, L., Sutherland, J., Marison, I., Moreillon, P., \& Mermod, N. (2003). Expression of a plant-derived peptide harboring water-cleaning and antimicrobial activities. Biotechnol. Bioeng, 81, 13-20. https://doi.org/10.1002/bit.10550

Suarez, M., Haenni, M., Canarelli, S., Fisch, F., Chodanowski, P., Servis, C., Michielin, O., Freitag, R., Moreillon, P., \& Mermod, N. (2008). Structure-function characterization and optimization of a plant-derived antibacterial peptide. Antimicrobial Agents and Chemotherapy, 49, 3847-3857. https://doi.org/10.1128/AAC.49.9.3847-3857.2005

Sunda, M., Rosillon, F., \& Taba, K. (2008). Contribution à l'étude de la désinfection de l'eau par photosensibilisation avec des extraits de plantes. European J. Water Quality, 39, 199-209. https://doi.org/10.1051/water/2008006

Tamsa, A. A. Nola, M., Lontsi, D. C., Nandjou, N. R. V., Nougang, M. E., Bricheux, G., \& Sime-Ngando, T. (2013). Comparison of the inhibition of commensally and enteropathogenic E. coli strains in the presence of Eucalyptus microcorys leaves extract in aquatic microcosm. Int. J. Curr. Microbiol. Appl. Sci., 2, 80-96.

Thevissen, K. A., Ghazi, G. W., De Samblanx, C., Brown, R. W., \& Brockaert, W. F. (1996). M Fungal membrane responses induced by plant defensins and thionins. J. Biol. Chem, 217, 15018-15025. https://doi.org/10.1074/jbc.271.25.15018

UN/WWD. (2006). Facts of water Resources. Repport 2 UN/WWD, A Summary of the united Nations World Water Development, UN, New York.

Weathers, P. J., \& Reed, K. (2014). Whole plant approaches to therapeutic use of Artemisia 
annua L. (Asteraceae). In T. Aftab, J. F. S. Ferreira, M. M. A. Khan, \&. M. Naeem (Eds.), Artemisia annua. Pharmacology and Biotechnology. Springer, London. https://doi.org/ 10.1007/978-3-642-41027-7_4

WHO. (2017a). Water quality and health - Review of turbidity: information for regulators and water suppliers. Retrieved from http://www.who.int/water_sanitation_health/publications/turbidity-technical-brief/en/

WHO, (2017b). Guidelines for drinking-water quality. Fourth edition incorporating the first addendum. Geneva: World Health Organization. Retrieved from http://www.who.int/water_sanitation_health/water-quality/guidelines/en/

WHO. (2002). Organisation Mondiale de la Santé (OMS) Rapport sur la medicine traditionnelle: Besoins et potentiel. $\mathrm{N}^{\circ}-4.6 \mathrm{P}$

WHO. (2011). Guidelines for drinking water quality, $4^{\text {th }}$ edition. WHO, Geneva, Swisserland. Zasloff, M. (2002). Antimicrobial peptides of multicellular organisms. Nature, 415, 389-395. https://doi.org/10.1038/415389a

\section{Copyright Disclaimer}

Copyright reserved by the author(s).

This article is an open-access article distributed under the terms and conditions of the Creative Commons Attribution license (http://creativecommons.org/licenses/by/3.0/). 